\title{
Ammonite succession at the Bajocian/Bathonian boundary in the Cabo Mondego region (Portugal)
}

\author{
SIXTO R. FERNÁNDEZ-LÓPEZ, MARIA HELENA HENRIQUES AND CHARLES MANGOLD
}

\begin{abstract}
The Cabo Mondego outcrops exposed along the cliffs, on the western margin of the Iberian Plate, show an expanded stratigraphic section of Lower Bathonian deposits containing abundant ammonoids. Upper Bajocian deposits correspond to similar facies, of muddy limestones alternating with marlstones, although ammonoids are scarce. A detailed succession of ammonites across the Bajocian/Bathonian boundary has been recognized at Cabo Mondego, which can form a useful bio- and chronostratigraphic standard for the Lusitanian Basin. The revision of previous collections from the classical section and new field samplings of two other separate sections allow the recognition through up to twenty metres of thickness, the highest zone of Bajocian (Parkinsoni Zone) and the lowest zone of Bathonian (Zigzag Zone). The Parkinsoni and the Zigzag zones established for NW European areas and belonging to the Northwest European Province, can be identified in the Lusitanian Basin, although the ammonite fossil assemblages are composed of Submediterranean taxa. However, a subdivision of the Parkinsoni Zone is not possible, due to the scarcity of well preserved ammonoids. The Zigzag Zone can be recognized and characterized as composed of two subunits (Parvum and Macrescens subzones) as represented in diverse European basins of the Submediterranean Province. Ammonite fossil assemblages of the Parvum Subzone may be grouped into two successive horizons, which are biochronostratigraphically equivalent to the subdivisions of the Convergens Subzone distinguished in the Digne-Barrême area (SE France). New biochronostratigraphic data on the Bigotitinae, youngest members of Leptosphinctinae and oldest members of Zigzagiceratinae are relevant in understanding the evolution and faunal turnover of the West Tethyan Perisphinctidae during earliest Bathonian. The ammonite succession at the Bajocian/Bathonian boundary in the Cabo Mondego region (Portugal) represents one of the most complete biostratigraphic records so far recognized on the Iberian Plate. $\square$ Ammonoids, biostratigraphy, chronostratigraphy, Iberia, Lusitanian Basin, Middle Jurassic, palaeobiogeography.
\end{abstract}

Sixto R. Fernández-López [sixto@geo.ucm.es], Departamento y UEI de Paleontología, Facultad de Ciencias Geológicas (UCM) e Instituto de Geología Económica (CSIC-UCM), 28040-Madrid, Spain; Maria Helena Henriques [hhenriq@dct.uc.pt], Departamento Ciências da Terra e Centro de Geociências, Faculdade de Ciências e Tecnologia, Universidade de Coimbra, 3000-272 Coimbra, Portugal; Charles Mangold, Université Claude-Bernard, Lyon-1,UFR des Sciences de la Terre et CNRS, UMR 5125, 27-43, bd du 11-Novembre-1918, 69622 Villeurbanne cedex, France;

Ammonites of the Bajocian/Bathonian boundary at the Cabo Mondego region are scarce in Upper Bajocian, but common in Lower Bathonian deposits. They are recorded in an expanded stratigraphic section which can be studied along several kilometres of coastal outcrops (Fig. 1). Several papers have described Lower Bathonian ammonites from the classical section of Cabo Mondego, $200 \mathrm{~m}$ WNW of the lighthouse (Section 90 in Fig. 1): Ruget-Perrot 1961; Elmi 1967, 1971; Elmi et al. 1971; Mangold 1971bc, 1990; Rocha et al. 1981, 1987; Mangold \& Rioult 1997. This classical section was modified and became difficult to access in 1990 due to the mining operations of several stone quarries. At the present time, there are two other outcrops which allow the study in detail of the Bajocian/Bathonian boundary of this region. The first, $500 \mathrm{~m} \mathrm{SW}$ of the lighthouse, on the coastline and studied by Fernández-López \& Henriques (2002) (Section 02; Figs $1 \& 2$ ). The second, $700 \mathrm{~m} \mathrm{~N}$ of the lighthouse, Section 04, was located at an active quarry front after 2004. At the present time, Cabo Mondego is of great geo-heritage significance because of its stratigraphic relevance for global correlation and other scientific issues; these range from educational purposes to purely aesthetic factors (Henriques \& Ramalho 2005).

The aim of this paper is to describe the ammonite succession at the Bajocian/Bathonian boundary in the Cabo Mondego region, taking into account data 


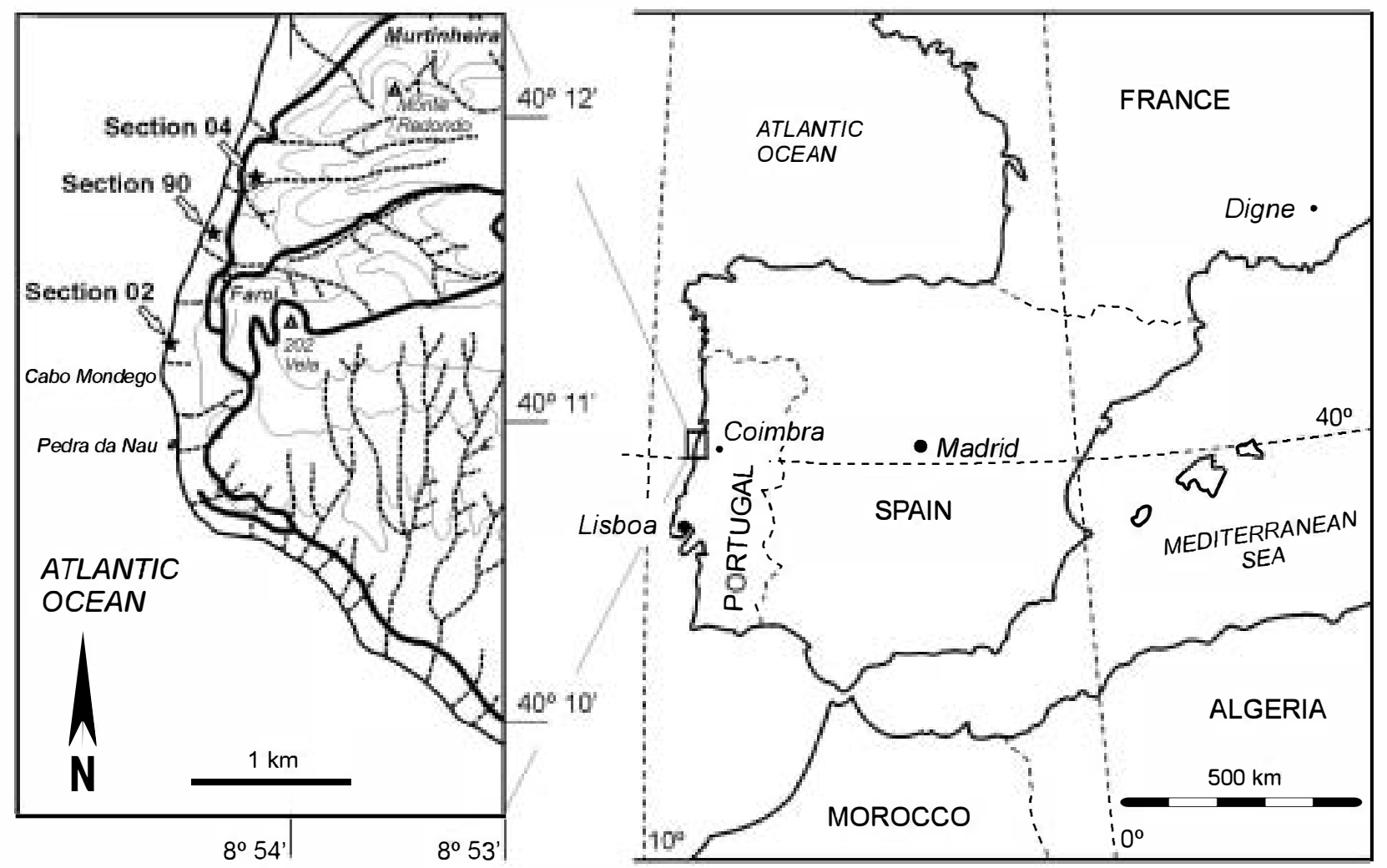

Fig. 1. Location maps of the three stratigraphic sections referring to the Bajocian/Bathonian boundary in the Cabo Mondego region (Portugal). From south to north, Section $02\left(40^{\bullet} 11^{\prime} 17^{\prime \prime}, 8^{\bullet} 54^{\prime} 34^{\prime \prime}\right)$, Section $90\left(40^{\bullet} 11^{\prime} 33^{\prime \prime}, 8^{\bullet} 54^{\prime} 25^{\prime \prime}\right)$ and Section $04\left(40^{\bullet} 11^{\prime} 52^{\prime \prime}, 8^{\bullet} 54^{\prime} 9^{\prime \prime}\right)$.

recorded in the three observable sections. The biochronostratigraphic data obtained in this region are interpreted and compared with those of other European basins.

\section{Ammonite taphonomy}

Upper Bajocian and Lower Bathonian deposits correspond to similar litho- and biofacies in the region of Cabo Mondego. They have been informally referred to the Brenha facies (Watkinson 1989; Azerêdo et al. 2002; Azerêdo \& Wright 2004), and formally included in the Cabo Mondego Formation (Soares et al. 1993; Azerêdo et al. 2003). Muddy limestones alternate with marlstones. Beds are normally under $50 \mathrm{~cm}$ thick, and marly intervals under $70 \mathrm{~cm}$. Thickening upwards sequences, of metric thickness, are common. Fining upwards sequences are scarce. Several planar based turbidites have been identified near the boundary between the Garantiana and Parkinsoni zones (such as the brown limestone bed named 106 in Fig. 3). Macrofossils include ammonoids, bivalves (Bositra), rhynchonellid brachiopods, crinoids and belemnites. Carbonized wood fragments of centimetric size are also present. Bioturbation structures are common (Zoophycos and Chondrites, in particular). These fossiliferous deposits were devel- oped in an open sea, on a distal and outer environment of carbonate ramp, below wave base.

In the Cabo Mondego region, the total number of studied Lower Bathonian ammonites is around 600 . Ammonoid remains are dominated by shells. Aptychi are very scarce and less than $1 \%$. Ammonoid shells are commonly recorded throughout the studied sections, but they rarely exceed $500 \mathrm{~mm}$ in diameter (less than $1 \%)$. Ammonoids are commonly preserved as concretionary internal moulds of resedimented shells. The sedimentary infill is similar in petrologic composition and texture to the sedimentary matrix. Internal moulds of shells partially filled with homogeneous sediments are predominant. Sedimentary infill of the ammonoid shells is generally absent in the innermost whorls and phragmocones without sedimentary infill (i.e. hollow ammonites) are common. Pyritic internal moulds of the innermost whorls or pyrite linings of some portions of whorl or flank, millimetric in size, occur (less than 10\%) in some levels. Concretionary internal moulds without septa, indicative of synsedimentary dissolution of septa are absent. However, aragonitic septa and shells have been dissolved during later diagenetic processes. Moldic porosity resulting from dissolution processes of shells and septa has been partially filled by spar cement in these deposits. 


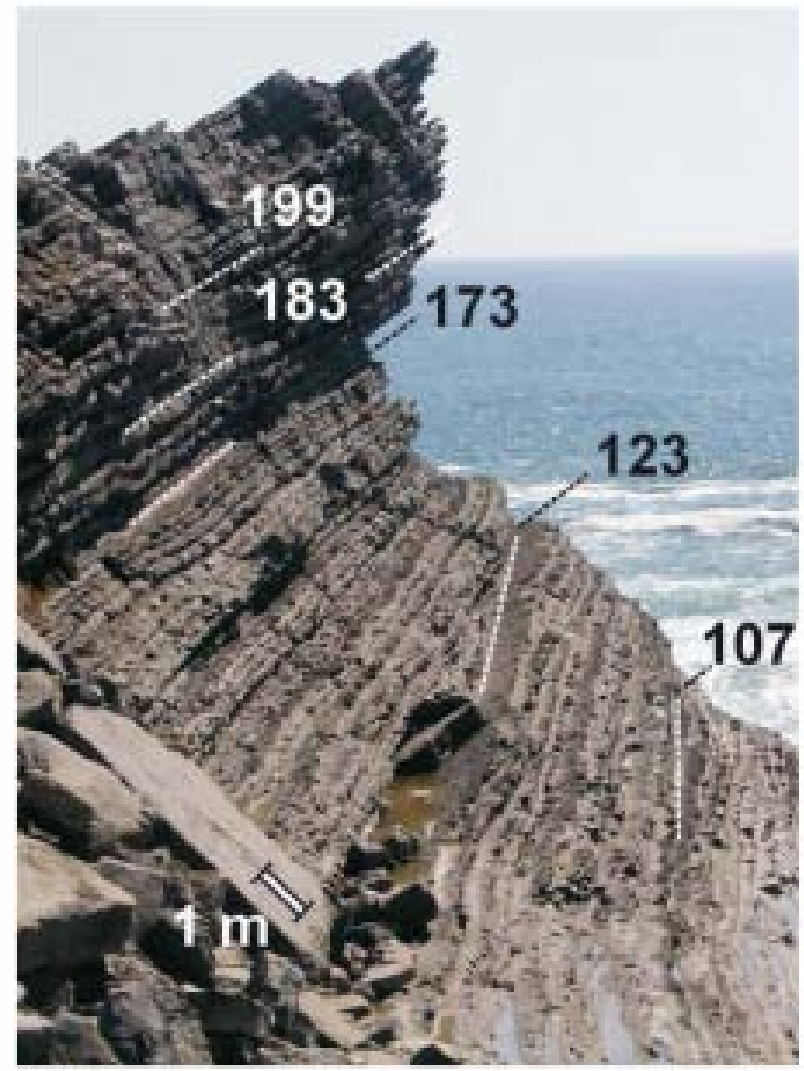

Fig. 2. Cabo Mondego Section 02. Marly interval 123 indicates the base of the Bathonian. Scale bar $1 \mathrm{~m}$.

Ammonite shells and internal moulds normally appear scattered in the sediment, showing no pattern of imbricate or encased regrouping. Ammonoid fossil assemblages show a high proportion of incomplete phragmocones and scarce complete shells with peristome. Ammonoid associations are dominated by reworked elements (i.e. resedimented and reelaborated elements sensu Fernández-López 1991, 1995). Accumulated elements, showing no evidence of reworking after laying on the seafloor, are virtually absent. Fragmented specimens of resedimented shells, displaced on the seafloor before their burial, are abundant, but generally bearing no signs of rounding, encrustation or bioerosion, due to low turbulence near the water/sediment surface. Internal moulds of resedimented shells usually display traces of continuous or discontinuous deformation by diagenetic compaction. Undeformed reelaborated internal moulds (i.e. exhumed and displaced before their final burial) are locally dominant, often showing disarticulation surfaces along septa with sharp margins or geopetal sedimentary infill reversed in position, but no evidence of compaction. The degree of removal (i.e. the ratio of reelaborated and resedimented elements to the whole of recorded elements) generally reach $100 \%$, but the degree of taphonomic heritage (i.e. the ratio of reelaborated elements to the whole of recorded elements) is low. There is no evidence for taphonomic condensation (i.e. mixture of fossils of different age or different chronostratigraphic units) in the ammonoid fossil assemblages. Ammonite mixed assemblages composed of specimens representing several biohorizons in a single bed or clay interval have not been identified.

Over 40 successive ammonite fossil assemblages have been recognized in the lowest Bathonian subzone. The degree of ammonite packing (estimated by the difference between the number of specimens and the number of fossiliferous levels divided by the number of fossiliferous levels) display low values, and the ammonite stratigraphical persistence (proportion of fossiliferous levels) display high values. Taphonic populations of type 3 are dominant but types 1 and 2 very scarce (Fernández-López 1991, 2000a). Taphonic populations of type 3 show uni- or polymodal and asymmetric distribution of size-frequencies, with negative skew, shells of juveniles are absent and adults are predominant. In contrast, taphonic populations of type 1, composed of monospecific shells showing unimodal and asymmetric distribution of size-frequencies, with positive skew, indicative of eudemic taxa and autochthonous biogenic production have been recognized among Leptosphinctinae of the Planisphinctes [m] Lobosphinctes $[\mathrm{M}]$ group. Taphonic populations of type 2 are composed of mono- or polyspecific shells of the same genus, which show unimodal and normal distribution of size-frequencies, with a high degree of kurtosis. Populations of type 2 contain a low proportion of microconchs and scarce shells of juvenile individuals, whereas shells of adult individuals are common, and they have been identified among Hecticoceratinae of the Nodiferites [m] - Zeissoceras [M] group.

Deposits of this ammonoid taphofacies are interpreted as having been developed in an hemipelagic environment, below wave base. The presence of resedimented and reelaborated ammonoids implies that some form of current flow, bypassing or winnowing affected the burial of concretionary internal moulds. However, the abundance of incomplete sedimentary internal moulds of ammonoid shells is indicative of a high rate of accumulation of sediment during biostratinomic processes.

\section{Ammonite bio- and chronostratigraphy}

Revising of previous collections belonging to the classical section (Fig. 3) and new field samplings of two separate sections (Fig. 4), along up to 20 metres of 


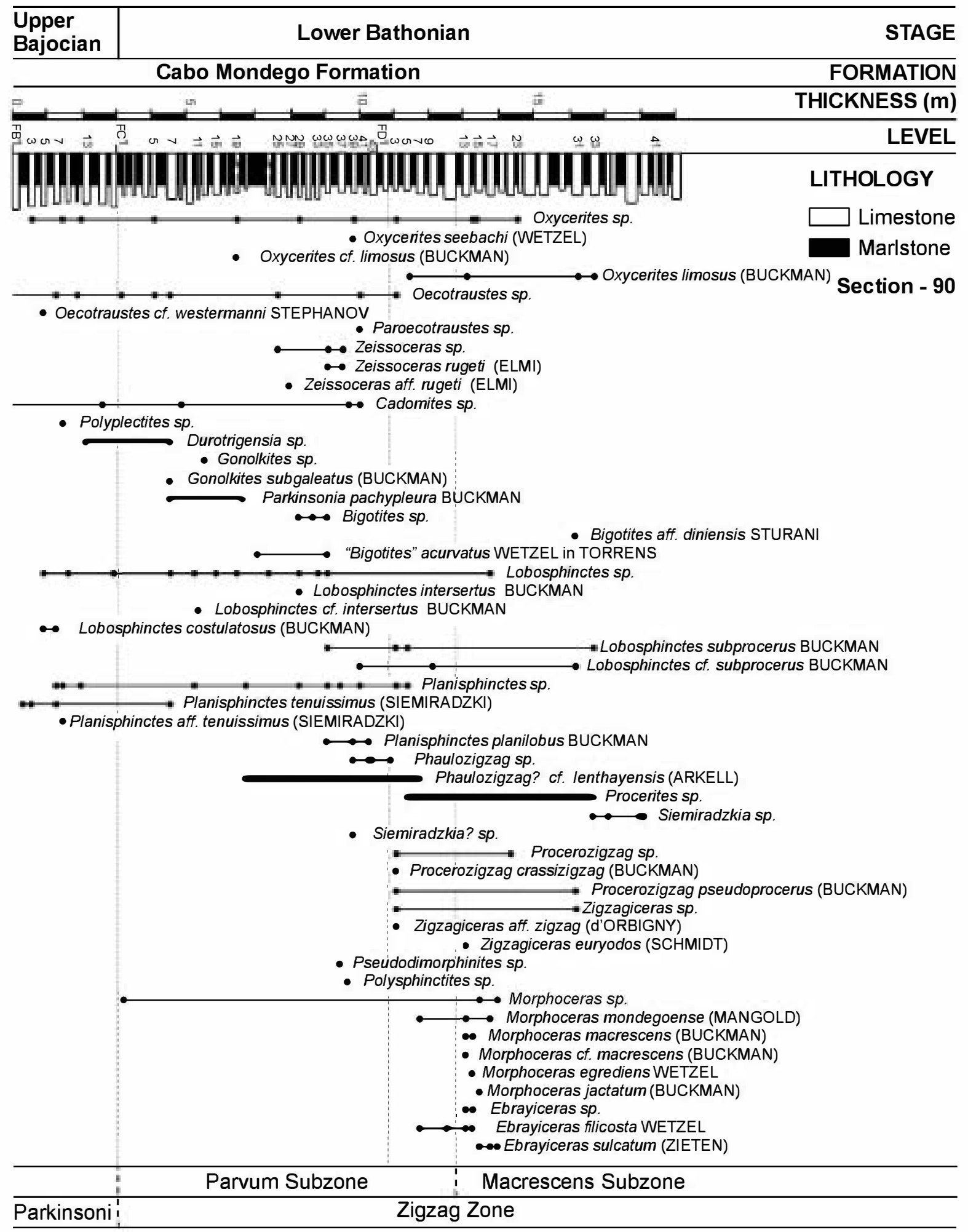

Fig. 3. Ammonite biochronostratigraphic data at the Bajocian/Bathonian boundary in Section 90 of Cabo Mondego. 


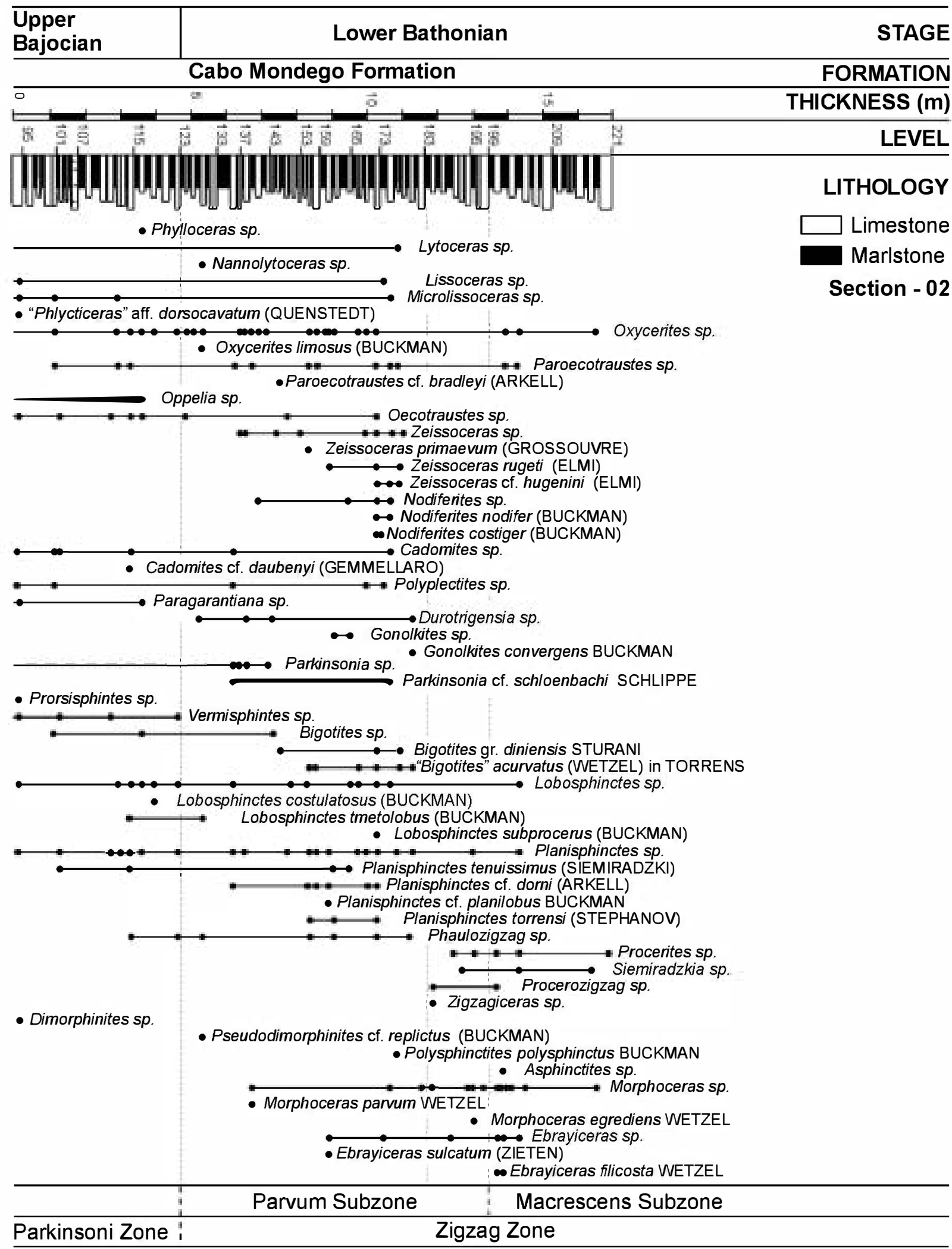

Fig. 4. Ammonite biochronostratigraphic data at the Bajocian/Bathonian boundary in Section 22 of Cabo Mondego. 
thickness, have allowed the recognition of the highest zone of Bajocian (Parkinsoni Zone) and the lowest zone of Bathonian (Zigzag Zone), taking into account ammonite taxonomic data. The dimorphic status and abundance of specimens will be indicated by $[\mathrm{M}]$ and $[\mathrm{m}]$ macroconch and microconch forms. R, C and VC indicate scarce, common and very common respectively.

\section{Upper Bajocian}

The Parkinsoni Zone is characterized by scarce specimens of Parkinsonia [m] Durotrigensia [M] and Paragarantiana [M, according to Gauthier 2003], which occur associated with the youngest representatives of Vermisphinctes $[\mathrm{m}]$ Prorsisphinctes $[\mathrm{M}]$ and Oppelia $[\mathrm{M}]$. In Section 2, two specimens of Dimorphinites [M] have been identified (level 22CM94 in Fig. 4). However, the scarcity of ammonites in the Parkinsoni Zone prevents recognition of subzones. In the three studied sections, the Parkinsoni Zone attains a minimum thickness of $5.0 \mathrm{~m}$ (interval $02 \mathrm{CM} 94$ 02CM122 in Fig. 4) and is overlaid by the Zigzag Zone, which attains a thickness of up to $16.0 \mathrm{~m}$ (interval 90FC1 90FD45 in Fig. 3; interval 02CM123 2 CM221 in Fig. 4). The following taxa have been identified:

Phylloceras sp. (R)

Lissoceras sp. $[\mathrm{M}](\mathrm{C})$

Microlissoceras sp. $[\mathrm{m}](\mathrm{R})$

'Phlycticeras' aff. dorsocavatum (Quenstedt) [M] (R)

Oppelia sp. [M] (R)

Oecotraustes sp. $[\mathrm{m}](\mathrm{R})$

Oecotraustes cf. westermanni Stephanov [m] (R)

Oxycerites sp. $[\mathrm{M}](\mathrm{R})$

Cadomites sp. [M] (C)

Cadomites cf. daubenyi (Gemmellaro) $[\mathrm{M}](\mathrm{R})$

Polyplectites sp. [m] (C)

Paragarantiana sp. $[\mathrm{M}](\mathrm{R})$

Durotrigensia sp. $[\mathrm{M}](\mathrm{R})$

Parkinsonia sp. $[\mathrm{m}](\mathrm{R})$

Prorsisphinctes sp. $[\mathrm{M}](\mathrm{R})$

Vermisphinctes sp. $[\mathrm{m}](\mathrm{R})$

Bigotites sp. $[\mathrm{M}+\mathrm{m}](\mathrm{R})$

Lobosphinctes sp. $[\mathrm{M}](\mathrm{R})$

Lobosphinctes costulatosus (Buckman) $[\mathrm{M}](\mathrm{R})$

Lobosphinctes tmetolobus (Buckman) $[\mathrm{M}](\mathrm{R})$

Planisphinctes sp. $[\mathrm{m}](\mathrm{C})$

Planisphinctes tenuissimus (Siemiradzki) $[\mathrm{m}](\mathrm{R})$

Planisphinctes aff. tenuissimus (Siemiradzki) $[\mathrm{m}](\mathrm{R})$

Phaulozigzag sp. $[\mathrm{m}](\mathrm{R})$

Dimorphinites sp. $[\mathrm{M}](\mathrm{R})$

\section{Lower Bathonian}

The Lower Bathonian boundary may be established by the lowest occurrence of the dimorphic group Morphoceras $[\mathrm{M}]$ Ebrayiceras $[\mathrm{m}]$. Ammonites allow recognition of the Parvum and Macrescens subzones of the Zigzag Zone, defined in the Submediterranean Province (Cariou et al. 1985; Mangold \& Rioult 1997). The lowermost subzone of the Bathonian yields common perisphinctids, oppelids and hecticoceratids: Planisphinctes $[\mathrm{m}] \quad$ Lobosphictes $[\mathrm{M}]$, Oxycerites [M] Paroecotraustes $[\mathrm{m}]$ and Nodiferites $[\mathrm{m}]$ Zeissoceras $[\mathrm{M}]$. The Parvum Subzone attains a thickness of $10 \mathrm{~m}$ (interval 90FC1 90FD11 in Fig. 3; interval 02CM123 02CM18s in Fig. 4). The following taxa have been identified:

Lytoceras sp. (R)

Nannolytoceras sp. (R)

Lissoceras sp. $[\mathrm{M}](\mathrm{R})$

Microlissoceras sp. $[\mathrm{m}](\mathrm{R})$

Oecotraustes sp. $[\mathrm{m}](\mathrm{R})$

Oxycerites sp. [M] (C)

Oxycerites limosus (Buckman) $[\mathrm{M}](\mathrm{R})$

Oxycerites cf. limosus (Buckman) $[\mathrm{M}](\mathrm{R})$

Oxycerites seebachi (Wetzel) $[\mathrm{M}](\mathrm{R})$

Paroecotraustes sp. (C)

Paroecotraustes cf. bradleyi (Arkell) $[\mathrm{m}](\mathrm{R})$

Zeissoceras sp. $[\mathrm{M}](\mathrm{C})$

Zeissoceras primaevum (Grossouvre) $[\mathrm{M}](\mathrm{R})$

Zeissoceras rugeti (Elmi) [M] (C)

Zeissoceras aff. rugeti (Elmi) $[\mathrm{M}](\mathrm{R})$

Zeissoceras cf. hugenini (Elmi) $[\mathrm{M}](\mathrm{R})$

Nodiferites sp. $[\mathrm{m}](\mathrm{C})$

Nodiferites nodifer (Buckman) $[\mathrm{m}](\mathrm{R})$

Nodiferites costiger (Buckman) $[\mathrm{m}](\mathrm{R})$

Cadomites sp. $[\mathrm{M}](\mathrm{R})$

Polyplectites sp. $[\mathrm{m}](\mathrm{R})$

Durotrigensia sp. $[\mathrm{M}](\mathrm{R})$

Gonolkites sp. [M] (R)

Gonolkites subgaleatus (Buckman) $[\mathrm{M}](\mathrm{R})$

Gonolkites convergens Buckman $[\mathrm{M}](\mathrm{R})$

Parkinsonia sp. [m] (R)

Parkinsonia pachypleura Buckman [m] (R)

Parkinsonia cf. schloenbachi Schlippe [m] (R)

Bigotites sp. [M] (R)

Bigotites gr. diniensis Sturani $[\mathrm{M}](\mathrm{R})$

'Bigotites' acurvatus (Wetzel) in Torrens [m] (R)

Lobosphinctes sp. $[\mathrm{M}](\mathrm{R})$

Lobosphinctes tmetolobus (Buckman) $[\mathrm{M}](\mathrm{R})$

Lobosphinctes intersertus Buckman $[\mathrm{M}](\mathrm{R})$

Lobosphinctes cf. intersertus Buckman $[\mathrm{M}](\mathrm{R})$

Lobosphinctes subprocerus (Buckman) $[\mathrm{M}](\mathrm{R})$

Lobosphinctes cf. subprocerus (Buckman) $[\mathrm{M}](\mathrm{R})$ 
Planisphinctes sp. [m] (C)

Planisphinctes tenuissimus (Siemiradzki) [m] (C)

Planisphinctes cf. dorni (Arkell) [m] (R)

Planisphinctes planilobus Buckman [m] (R)

Planisphinctes cf. planilobus Buckman [m] (R)

Planisphinctes torrensi (Stephanov) $[\mathrm{m}](\mathrm{R})$

Phaulozigzag sp. [m] (R)

Phaulozigzag? cf. lenthayensis (Arkell) [m] (R)

Siemiradzkia? sp. [m] (R)

Pseudodimorphinites sp. [M] (R)

Pseudodimorphinites cf. replictus (Buckman) (R)

Polysphinctites sp. [m] (R)

Polysphinctites polysphinctus Buckman [m] (R)

Morphoceras sp. [M] (R)

Morphoceras parvum (Wetzel) [M] (R)

Ebrayiceras sp. [m] (R)

Ebrayiceras sulcatum (Zieten) [m] (R)

The following taxa have been identified in the upper part of the Parvum Subzone, through 1.5-2 m of thickening upwards beds, in the stratigraphic interval beginning with the lowest occurrence of Zigzagiceras [m] - Procerozigzag [M] and underlying the lowest occurrence of Morphoceras macrescens (interval 90FD390FD11 in Fig. 3; interval 02CM183-02CM198 in Fig. 4):

Oxycerites sp. [M] (R)

Oxycerites limosus (Buckman) $[\mathrm{M}](\mathrm{R})$

Oecotraustes sp. [m] (R)

Lobosphinctes subprocerus (Buckman) $[\mathrm{M}](\mathrm{R})$

Lobosphinctes cf. subprocerus (Buckman) $[\mathrm{M}](\mathrm{R})$

Planisphinctes sp. $[\mathrm{m}](\mathrm{R})$

Phaulozigzag sp. [m] (R)

Phaulozigzag? cf. lenthayensis (Arkell) [m] (R)

Procerites sp. $[\mathrm{M}](\mathrm{R})$

Siemiradzkia sp. [m] (R)

Procerozigzag sp. $[\mathrm{M}](\mathrm{R})$

Procerozigzag crassizigzag (Buckman) $[\mathrm{M}](\mathrm{R})$

Procerozigzag pseudoprocerus (Buckman) $[\mathrm{M}](\mathrm{R})$

Zigzagiceras sp. [M] (R)

Zigzagiceras aff. zigzag (d'Orbigny) [m] (R)

Morphoceras sp. [M] (C)

Morphoceras egrediens Wetzel [M] (R)

Morphoceras mondegoense (Mangold) $[\mathrm{M}](\mathrm{R})$

Ebrayiceras sp. $[\mathrm{m}](\mathrm{C})$

Ebrayiceras filicosta Wetzel [m] (R)

The second subzone of the Zigzag Zone (interval from levels 90FD13 in Fig. 3 and from 02CM199 in Fig. 4), characterized by the lowest occurrence of Morphoceras macrescens (Buckman), belongs to the Submediterranean Macrescens Subzone:
Oxycerites sp. [M] (C)

Oxycerites limosus (Buckman) $[\mathrm{M}](\mathrm{R})$

Paroecotraustes sp. [m] (R)

Bigotites aff. diniensis Sturani $[\mathrm{M}](\mathrm{R})$

Lobosphinctes sp. $[\mathrm{M}](\mathrm{R})$

Lobosphinctes subprocerus (Buckman) $[\mathrm{M}](\mathrm{R})$

Lobosphinctes cf. subprocerus (Buckman) $[\mathrm{M}](\mathrm{R})$

Planisphinctes sp. $[\mathrm{m}](\mathrm{R})$

Procerites sp. $[\mathrm{m}](\mathrm{C})$

Siemiradzkia sp. [m] (C)

Procerozigzag sp. $[\mathrm{M}](\mathrm{R})$

Procerozigzag pseudoprocerus (Buckman) [M] (R)

Zigzagiceras sp. [m] (R)

Zigzagiceras euryodos (Schmidt) [m] (R)

Asphinctites sp. [M] (R)

Morphoceras sp. [M] (C)

Morphoceras macrescens (Buckman) [M] (C)

Morphoceras cf. macrescens (Buckman) [M] (R)

Morphoceras mondegoense (Mangold) [M] (R)

Morphoceras egrediens Wetzel [M] (R)

Morphoceras jactatum (Buckman) [M] (R)

Ebrayiceras sp. [m] (C)

Ebrayiceras filicosta Wetzel [m] (C)

Ebrayiceras sulcatum (Zieten) $[\mathrm{m}](\mathrm{R})$

\section{Palaeobiogeographical and evolutionary remarks}

Diverse zonal schemes have been established in Europe, for the Upper Bajocian and Lower Bathonian, due to faunal differences within the West Tethyan Subrealm (Fig. 5). A northern European faunal region or Northwest European Province, from Britain to southern Germany, has been distinguished by several authors (Westermann 1958; Hahn 1969, 1970; Callomon et al.

\begin{tabular}{|c|c|c|c|c|c|c|}
\hline \multirow{5}{*}{ 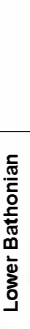 } & \multicolumn{2}{|c|}{$\begin{array}{l}\text { NW European } \\
\text { Province } \\
\text { NW Europe: England, } \\
\text { Lorraine, Alsace, } \\
\text { Germany. }\end{array}$} & \multicolumn{2}{|c|}{$\begin{array}{c}\text { Submediterranean } \\
\text { Province } \\
\text { Centre-west France, Nièvre, } \\
\text { Jura, Mâconnais, Portugal, } \\
\text { Iberian Basin }\end{array}$} & \multicolumn{2}{|c|}{$\begin{array}{c}\text { Mediterranean } \\
\text { Province } \\
\text { Betic Basin }\end{array}$} \\
\hline & \multicolumn{2}{|c|}{ Tenuiplicatus } & 론 & Tenuiplicatus & \multirow{4}{*}{$\begin{array}{l}\text { 疋 } \\
\text { N } \\
\stackrel{N}{N}\end{array}$} & Postpollubrum \\
\hline & \multirow{3}{*}{$\begin{array}{l}\text { D } \\
\mathbb{N} \\
\stackrel{N}{N}\end{array}$} & Yeovilensis & 䢍 & Recinctus & & Yeovilensis \\
\hline & & Macrescens & 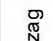 & Macrescens & & Macrescens \\
\hline & & Convergens & $\dot{N}$ & Parvum & & Dimorphitiformis \\
\hline \multirow{3}{*}{$\begin{array}{l}\frac{5}{0} \\
\frac{\pi}{0} \\
\frac{0}{0} \\
\frac{0}{2} \\
\frac{2}{2} \\
\frac{2}{2}\end{array}$} & \multirow{3}{*}{ 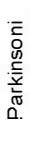 } & Bomfordi & \multirow{3}{*}{ 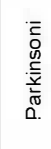 } & Bomfordi & \multirow{3}{*}{ 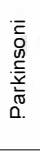 } & \multirow[t]{2}{*}{ Dimorphus } \\
\hline & & \multirow{2}{*}{ Truellei } & & Densicosta & & \\
\hline & & & & Acris & & Daubenyı \\
\hline
\end{tabular}

Fig. 5. Ammonite zones and subzones of the Uppermost Bajocian and Lower Bathonian in the so-called Northwest European (Westermann \& Callomon 1988; Callomon \& Cope 1995), Sub-Mediterranean (Mangold 1990; Rioult et al. 1997; Mangold \& Rioult 1997) and Mediterranean (Sandoval 1983, 1990) provinces of Europe. 
1987; Westermann \& Callomon 1988; Callomon \& Cope 1995; Page 1996a, b; Dietze \& Chandler 1997; Dietze \& Schweigert 2000; Dietze et al. 2002, 2004) giving particular relevance to the abundance of Parkinsonids. In contrast, Phylloceratina and Lytoceratina characterizing the Mediterranean or West Tethyan Province (Cariou et al. 1985) are very common in the Subbetic Basin (Mangold 1981; Sandoval 1983, 1990; Sandoval et al. 2001), Sicily (Wendt 1963, 1971; Galácz 1999; Pavia et al. 2002; Martire \& Pavia 2004), Subalpine Basin (Sturani 1967; Pavia 1973; Torrens 1987; Innocenti et al. 1988; Olivero et al. 1997), Alps (Krystyn 1972), Western Carpathians (Schlögl \& Rakús 2004; Schlögl et al. 2005), Hungary (Galácz 1980, 1994; Geczy \& Galácz 1998), Serbia (Mihajlovic 1969) and Bulgaria (Stephanov 1966, 1972). Parkinsonids characterizing the Northwest European Province, as well as Phylloceratids and Lytoceratids characterizing the Mediterranean Province, are very scarce in the Sub-Mediterranean areas, such as Portugal, Iberian Basin, centre-west France, Nièvre, Mâconnais, Jura, Central Poland and Caucasus (Tserethely 1968; Elmi \& Alméras 1984; Mangold 1990; Beznosov \& Mitta 1993, 1998, 2000; Rioult et al. 1997; Mangold \& Rioult 1997; Fernández-López 2000b; Matyja \& Wierzbowski 2000; Mitta \& Seltzer 2002; Moyne et al. 2004; Zaton \& Marynowski 2004).

In the Lusitanian Basin, Upper Bajocian and Lower Bathonian Phylloceratina and Lytoceratina represent less than $1 \%$ of the whole of ammonoids and parkinsonids are very scarce (less than 5.0\%). The uppermost Bajocian zone, the Parkinsoni Zone, is poorly characterized due to the scarcity of well preserved ammonoids. Specimens of Dimorphinites [M] occur in the Cabo Mondego region, but possibilities for correlation of the youngest Bajocian ammonoids with those from Mediterranean and NW European provinces remain quite limited.

Specimens of the family Perisphinctidae are very common $(41.5 \%$ in Section 90, 37.7\% in Section 02, Fig. 6) and correspond to three subfamilies: Leptosphinctinae (Buckman 1929), Bigotitinae (Westermann, 1956) and Zigzagiceratinae (Buckman, 1920) (Fig. 9). Bajocisphinctes and Bigotites represent two successive taxonomic groups of West Tethyan Perisphinctidae. Bajocisphinctes $[\mathrm{M}]$ - Microbajocisphinctes $[\mathrm{m}]$, the earliest forms of Bigotitinae derived by proterogenesis from Leptosphinctes $[\mathrm{M}]-$ Cleistosphinctes $[\mathrm{m}]$, occur in the Garantiana Zone (Fernández-López 1985, 1987; Rocha et al. 1987). Bigotites $[\mathrm{M}+\mathrm{m}]$, showing relatively simple sutures and shells larger in size, represents a hypermorphic and palingenetic change from Bajocisphintes during the Garantiana Biochron. Perisphinctidae of the dimorphic couple Bigotites gr. diniensis Sturani $[\mathrm{M}]$ - 'Bigotites' acurvatus (Wetzel) in Torrens [ $\mathrm{m}]$, with suspensive lobe not strongly retracted, have been recently discovered, although they are scarce (Figs 7-8). These

\section{Parkinsoni Zone}

Zigzag Zone

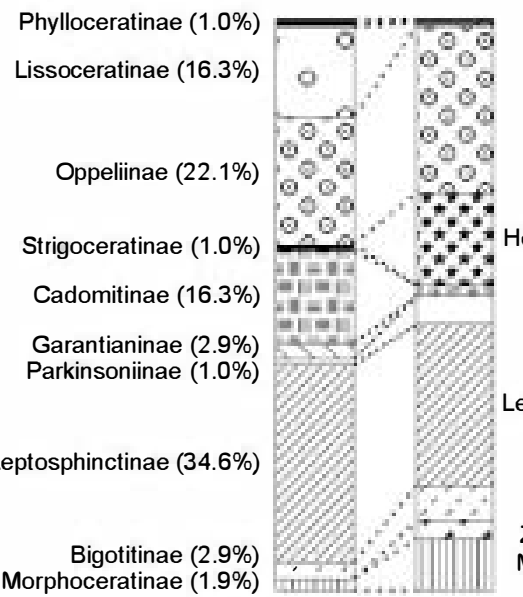

Lytoceratinae $(0.7 \%)$ Lissoceratinae (0.3\%)

Oppeliinae (29.5\%)

Hecticoceratinae (16.2\%)

Cadomitinae $(1.7 \%)$

Parkinsoniinae (5.0\%)

Leptosphinctinae (28.1\%)

Bigotitinae (6.3\%) Zigzagiceratinae (3.3\%) Morphoceratinae (8.9\%)

Fig. 6. Distribution of percentage of ammonite taxonomic groups in the Parkinsoni Zone (104 specimens) and Zigzag Zone (302 specimens) from Section 2 of Cabo Mondego. Similar percentages have been obtained in the Zigzag Zone from Section 90: Oppeliinae $20.0 \%$, Hecticoceratinae $16.9 \%$, Cadomitinae $3.1 \%$, Parkinsoniinae $4.6 \%$, Leptosphinctinae 4.6\%, Zigzagiceratinae 36.9\%, Morphoceratinae $13.9 \%$.
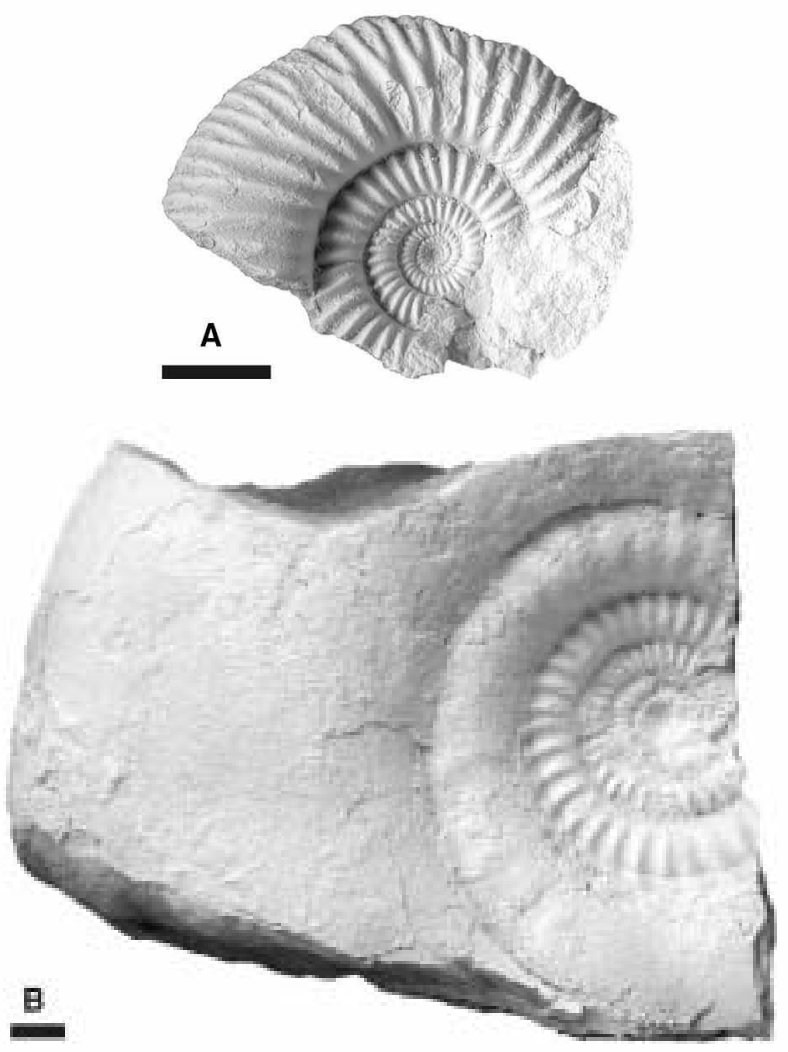

Fig. 7. Incomplete phragmocones of Bigotites gr. diniensis Sturani [M] from the Cabo Mondego region (Portugal). Parvum Subzone, Zigzag Zone, Bathonian. Scale bars $1 \mathrm{~cm}$. $\square$ A. Specimen $2 \mathrm{CM} 172 / 9 ; \mathbf{D}=$

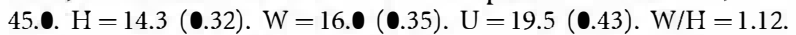

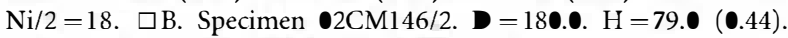
$\mathrm{W}=62 . \bullet$ (๑.34). $\mathrm{U}=72 . \bullet(\bullet .40)$. $\mathrm{W} / \mathrm{H}=\boldsymbol{\bullet} .78$. 


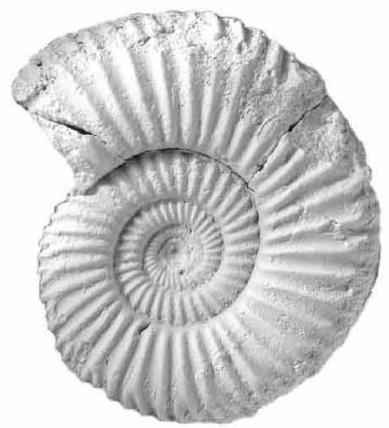

A

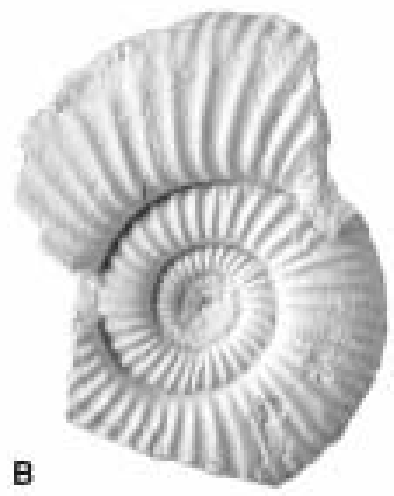

C

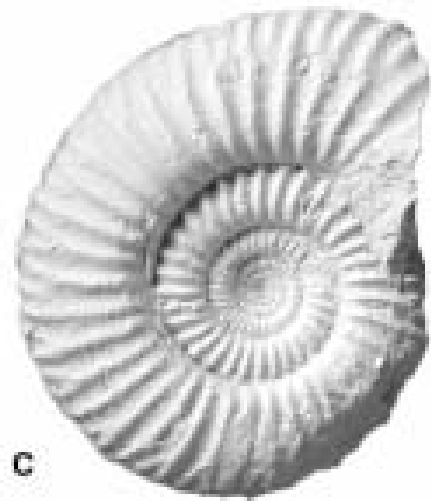

Fig. 8. Incomplete phragmocones of 'Bigotites' acurvatus (Wetzel) in Torrens [m] from the Cabo Mondego region (Portugal). Parvum Subzone, Zigzag Zone, Bathonian. Scale bar $1 \mathrm{~cm}$. $\square$ A. Specimen $\bullet 2 \mathrm{CM} 172 / 6 . \mathbf{D}=43 . \bullet \mathrm{H}=15 . \bullet(\boldsymbol{\bullet} .35)$. W $=14 . \bullet(\bullet .32) . \mathrm{U}=17.5(\boldsymbol{\bullet} .41)$. W/H $=\mathbf{0} .93$. Ni/2=

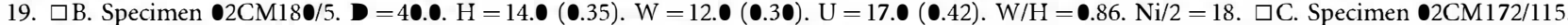
$\square=49 . \bullet . \mathrm{H}=16 . \bullet(\bullet .33) . \mathrm{W}=13 . \bullet(\bullet .26) . \mathrm{U}=21.5(\bullet .44) . \mathrm{W} / \mathrm{H}=\boldsymbol{\bullet} .81 . \mathrm{Ni} / 2=18$.

microconch forms are more strongly ribbed than Planisphinctes planilobus Buckman, show nodes in the bifurcation of the primary ribs, and are less stoutly whorled than 'Bigotites' acurvatus (Wetzel 1937, p. 96, pl. 10, fig. 12). They are also known in the stratigraphic interval from bed 23 to bed 14, in the Ravin du Bés section, at Bas Auran district (cf. Sturani 1967, pp. 9, 39, pl. 7, Fig. 3; Torrens 1987, pp. 106-107, pl. 4, figs. 1, 5, 6). It is important to remark for chronocorrelation purposes that this dimorphic couple present a distribution restricted to the Parvum Subzone, homotaxial and similarly positioned in the type area of the species (DigneBarrême area; Horizon (1a) with Bigotites diniensis in Innocenti et al . 1988). The youngest Bathonian records of Bigotites $[\mathrm{M}+\mathrm{m}]$ appear to be from Portugal, at the lower part of the Macrescens Subzone (level 90FD31, Fig. 3). Planisphinctes $[\mathrm{m}]$ - Lobosphictes $[\mathrm{M}]$, with relatively complex sutures and well retracted suspensive lobe, are the most common ammonites in the Parvum Subzone. Lobosphinctes has been believed as derivative of Bigotites and comprising the oldest Zigzagiceratinae (cf. Arkell et al. 1957; Arkell 1958; Sturani 1967; Mangold 1971ab; Sandoval 1983) as well as the youngest Leptosphinctinae (Torrens 1987; Innocenti et al. 1988). Lobosphinctes lack the parabolic nodes or zigzag stage of ribbing characteristic of the earliest whorls of Zigzagiceratinae. However, they also lack the smooth band on external region enlarging segmentally after the constrictions characteristic of Vermisphinctes [m] - Prorsisphinctes [M], as well as the relatively simple sutures and the nodes in the bifurcation of the primary ribs characteristic of Bigotites $[\mathrm{M}+\mathrm{m}]$. Therefore, in accordance with the sutural complexity, ornamentation and biochronostratigraphic distribution, it seems more probably that the dimorphic group Planisphinctes $[\mathrm{m}]-$ Lobosphictes $[\mathrm{M}]$ represents a direct derivative of some Late Bajocian species of the group of Vermisphinctes $[\mathrm{m}]$ - Prorsisphinctes $[\mathrm{M}]$, as suggested by Stephanov (1966). Procerites [M] and Siemiradzkia $[\mathrm{m}]$, showing parabolic nodes in the earliest whorls as proterogenetic character, are common in the Macrescens Subzone and occur in the upper part of the Parvum Subzone. Involute and fine-ribbed Phaulozigzag $[\mathrm{m}]$, with close ribbing, without parabolic nodes, larger in size and older than Siemiradzkia $[\mathrm{m}]$ occur at the Bajocian/Bathonian boundary, associated with involute

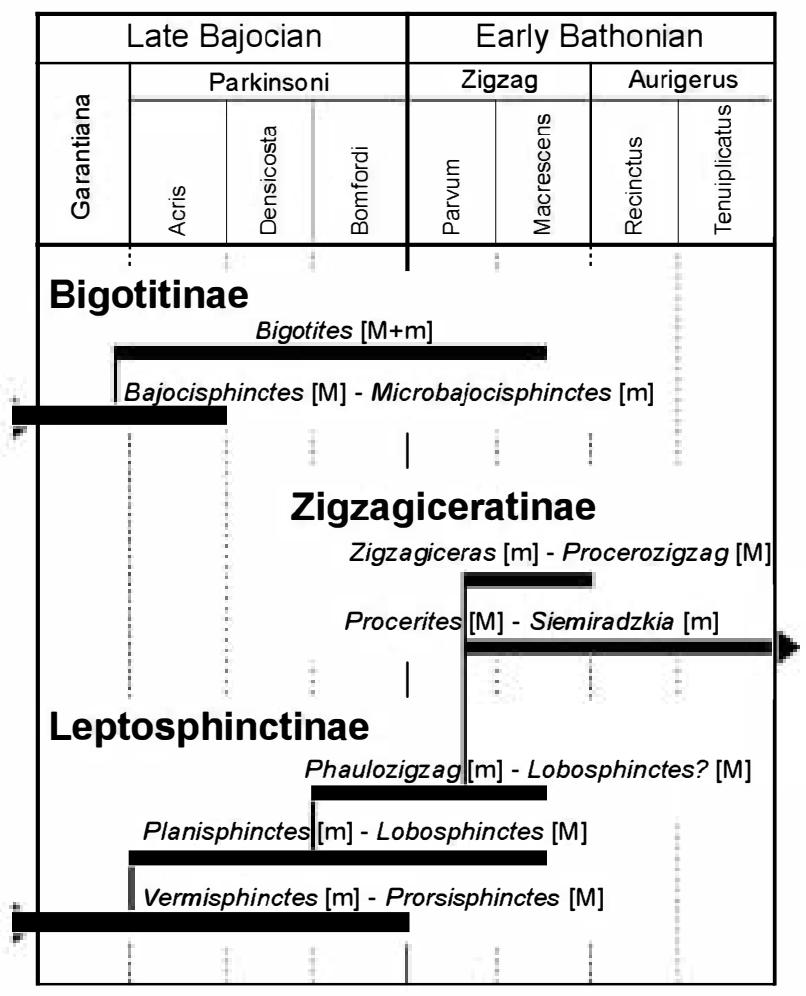

Fig. 9. Phylogenetic scheme of the last genera of Leptosphinctinae, two genera of Bigotitinae and initial members of Zigzagiceratinae recorded at the Bajocian/Bathonian transition in the Cabo Mondego region (Portugal). 
and rather finely ribbed macroconchs provisionally attributed to Lobosphinctes? [M] (Fig. 9). Specimens of the dimorphic couple Zigzagiceras [m] - Procerozigzag $[\mathrm{M}]$ are very scarce, showing relatively complex sutures also and being the earliest forms from the upper part of the Parvum Subzone. Representatives of Franchia [M+ $\mathrm{m}]$ have not been so far identified in Cabo Mondego. However, the phylogenetic derivation ofZigzagiceras $[\mathrm{m}]$ - Procerozigzag [M] from Franchia $[\mathrm{M}+\mathrm{m}]$ is not firmly established. On the one hand, the relative age of Franchia $[\mathrm{M}+\mathrm{m}]$ proposed as older than the first appearance datum of Zigzagiceras [m] - Procerozigzag [M] (Torrens 1987; Innocenti et al. 1988) needs to be tested in diverse regions. In Bas Auran, this particular genus occurs in association with the youngest representatives of Lobosphinctes tmetolobus and Lobosphinctes subprocerus, overlaying the Horizon with Bigotites diniensis, but it is also recorded below and in the lowest occurrence level of Morphoceras macrescens (in the stratigraphic interval from bed 13 to bed 12 at the Ravin du Bés, Bas Auran). Being bed 12 the level of lowest occurrence of Morphoceras macrescens, after new results obtained by several members of the Bathonian Working Group, the upper horizon (1b) of the Convergens (= Parvum) Subzone characterized by the onset of Zigzagiceratinae of the subgenus Zigzagiceras (Franchia) corresponds exclusively to the bed 13 , and can be biochronostratigraphically correlated with the Cabo Mondego intervals 90FD3-90FD11 (Fig. 3) and 02CM183-02CM198 (Fig. 4). Consequently, Franchia $[\mathrm{M}+\mathrm{m}]$ in Bas Auran show a homotaxial distribution with regard to the lowest occurrence of Zigzagiceras [m] - Procerozigzag [M] in Cabo Mondego. On the other hand, taking into account the greater sutural complexity of Zigzagiceras [m] Procerozigzag [M], the immediate predecessor of Franchia $[\mathrm{M}+\mathrm{m}]$ can be probably identified in a primitive species of Zigzagiceras [m] - Procerozigzag [M], rather than in a derived species of Bigotites, from the Parvum Subzone.

Among the Morphoceratidae (13.9\% in Section 90, 8.9\% in Section 02), Morphoceras [M] - Ebrayiceras [m] are one of the most common ammonites in the lower part of the Macrescens Subzone, but they are scarce at the Bajocian/Bathonian boundary. Rare Pseudodimorphinites $[\mathrm{M}$, according to Seyed-Emami et al. 1989; Mangold 1997; Dietze et al. 2002], Asphinctites $[\mathrm{M}]$ and Polysphinctites $[\mathrm{m}]$ occur in the Zigzag Zone also. Bathonian parkinsonids of the genera Parkinsonia $[\mathrm{m}]$, Durotrigensia $[\mathrm{M}]$ and Gonolkites $[\mathrm{M}]$ are scarce (4.6\% in Section 90, 5.0\% in Section 02).

Representatives of the family Oppeliinae, Oxycerites [M] - Paroecotraustes [m], are common $(20.0 \%$ in Section 90, 29.5\% in Section 02). Representatives of Hecticoceratinae, Nodiferites $[\mathrm{m}]$ - Zeissoceras $[\mathrm{M}]$ are abundant in some beds of the middle part of the
Parvum Subzone (16.9\% in Section 90, 16.2\% in Section 02), being a conspicuous component of the Submediterranean faunas of Western Tethys. The oldest identified species of Zeissoceras $[\mathrm{M}]$ from Portugal correspond to Z. primaevum (Grossouvre) at the lower part of the Parvum Subzone (02CM154). Z. rugeti (Elmi) associated with Z. cf. hugenini (Elmi) are abundant at the middle part of the Parvum Subzone. Very scarce are the families Stephanoceratidae (3.1\% in Section $90,1.7 \%$ in Section 02) and Lissoceratidae (0.3\% in Section 02). Consequently, the Parkinsoni Zone (Upper Bajocian) and the lowermost Zigzag Zone (Lower Bathonian) established for NW Europe areas can be identified in the Cabo Mondego region, although the ammonite fossil assemblages are composed of Submediterranean taxa.

\section{Conclusions}

The ammonite succession at the Bajocian/Bathonian boundary in the Cabo Mondego region (Portugal) provides one of the most complete biostratigraphical records recognized on the Iberian Plate. Over 40 successive assemblages have been recognized in the lowest Bathonian subzone (the Parvum Subzone). These successive ammonite fossil assemblages are composed of Submediterranean taxa, but they allow a correlation to the zonal scale with diverse basins of the Mediterranean and NW European provinces. The occurrence of Bigotites gr. diniensis $[\mathrm{M}+\mathrm{m}]$ in Cabo Mondego in the Parvum Subzone represents a new criterion for chronocorrelation with the Digne-Barrềme area, and is also useful for understanding the evolution of the West Tethyan Perisphinctidae during earliest Bathonian. These results are crucial for the establishment of a Bathonian global stratotype section and point (GSSP) of which the Ravin du Bés section (Bas Auran district) is the leading candidate.

Acknowledgements. - This work is a contribution to the Project CGL2004-0694/BTE (MEC-CSIC). We thank Serge Elmi (Université Claude Bernard, Lyon), Kevin Page (School of Earth, Ocean and Environmental Sciences, University of Plymouth) and Svend Stouge (Editor-in-Chief of Lethaia, Geological Museum, Copenhagen) for constructive suggestions of the manuscript.

\section{References}

Arkell, W.J. 1951 - 1959: A monograph of English Bathonian ammonites. 264 pp. Palaeontographical Society, London.

Arkell, W.J., Kummel, B. \& Wright, C.W 1957: Mesozoic Ammonoidea. In Moore, R.C. (ed.): Treatiseon Invertebrate Paleontology, Part L, Mollusca 4, Cephalopoda, Ammonoidea, L80--L465. Geological Society of America and University of Kansas Press, Boulder (Colorado)and Lawrence (Kansas).

Azerêdo, A.C. \& Wright, V.P. 2004: Multi-scale signatures and events in carbonate systems (Middle to early Upper Jurassic, Lusitanian 
Basin). In Duarte, L.V. \& Henriques, M.H. (eds): Field Trip Guidebook, Volume 1. Carboniferous and Jurassic carbonate platforms of Iberia. 23rd IAS Meeting of Sedimentology, 73-91. International Association of Sedimentologists, Coimbra.

Azerêdo, A.C., Wright, V.P. \& Ramalho, M.M. 2002: The Middle-Late Jurassic forced regression and disconformity in central Portugal: eustatic, tectonic and climatic effects on a carbonate ramp system. Sedimentology 49, 1339-1370.

Azerêdo, A.C., Duarte, L.V., Henriques, M.H. \& Manuppella, G. 2003: Da dinâmica continental no Triásico aos mares do Jurássico Inferior e Médio. Cadernos de Geologia de Portugal 2003, $1-43$.

Beznosov, N.V. \& Mitta, V.V. 1993: Upper Bajocian and Bathonian ammonites of the Northern Caucasus and Central Asia. 347 pp. VNIGRI, Nedra, Moscow.

Beznosov, N.V. \& Mitta, V.V. 1998: Catalogue of Ammonitida and key sections of the Upper Bajocian - Lower Bathonian of North Caucasus. 72 pp. VNIGRI, Nedra, Moscow.

Beznosov, N.V. \& Mitta, V.V. 2000: Jurassic geology and ammonites of Great Balkhan (Western Turkmenistan). 115 pp. VNIGRI, Nedra, Moscow.

Buckman, S.S. 1909-1930: Yorkshire Type Ammonites \& Type Ammonites. $790 \mathrm{pl}$. Welsey \& Son-Wheldon Welsey, London.

Callomon, J.H. \& Cope J.C.W. 1995: The Jurassic Geology of Dorset. In Taylor, P.D. (ed.): Field Geology of the British Jurassic, 51-104. Geological Society, London

Callomon, J.H., Dietl, G., Galácz, A., Grandl, H., Niederhöf er, H.J. \& Zeiss, A. 1987: Zur Stratigraphie des Mittel- und unteren Oberjuras in Sengenthal bei Neumarkt/Opf. (Fränkische Alb). Stuttgarter Beiträge zur Naturkunde 132, 1-53.

Cariou, E., Contini, D., Dommergues, J.L., Enay, R., Geyssant, J.R., Mangold C. \& Thierry J. 1985: Biogéographie des Ammonites et évolution structurale de la Téthys au cours du Jurassique. Bulletin de la Société géologique de France 1, 679-697.

Dietze, V. \& Chandler, R.B. 1997: New Ammonites from the Zigzag Bed of Dorset. Dorset Proceedings 119, 109-116.

Dietze, V. \& Schweigert, G. 2000: Zur Stratigraphie und Ammonitenführung des ber-Bajociums und Bathoniums, insbesondere der Zigzag-Zone, Convergens-Subzone, von Röttingen (östliche Schwäbische Alb, Südwestdeutschland). Stuttgarter Beiträge zur Naturkunde $284,1-15$.

Dietze, V., Mangold, Ch. \&. Chandler, R.B. 2002: Two new species of Berbericeras Roman, 1933 (Morphoceratidae, Ammonitina) from the Zigzag Bed (Lower Bathonian, Zigzag Zone) of Waddon Hill (Broadwindsor, Dorset, Southern England). Stuttgarter Beiträge zur Naturkunde 324, 1-11.

Dietze, V., Ermer, G., Görlich, M., Ivankic, Z., Krieger, Th. \& Röper, M. 2004: Das Bajocium und Bathonium (Mittel-Jura) bei Greding (Fränkische Alb, Süddeutschland). Archaeopteryx 22, 61-74.

Elmi, S. 1967: Le Lias supérieur et le Jurassique moyen de l'Ardèche. Documents des Laboratoires de Géologie Lyon 19, 509-845.

Elmi, S. 1971: Les faunes à Prohecticoceras (Oppeliidae, Ammonitina) du Bathonien inférieur et moyen des confins algéro-marocains. Geobios 4, 243-264.

Elmi, S. \& Alméras, Y. 1984: Physiography, palaeotectonics and palaeoenvironments as controls of changes in ammonite and brachiopod communities (an example from the early and middle Jurassic of western Algeria). Palaeogeography, Palaeoclimatology, Palaeoecology 47, 347-360.

Elmi, S., Mangold, Ch., Mouterde, R. \& Ruget, Ch. 1971: Révision de l'étage Bathonien au Cap Mondego (Portugal). Annales Instituti Geologici Publici Hungarici 54, 439-450.

Fernández-López, S. 1985: El Bajociense en la Cordillera Ibérica. 850 pp. Departamento Paleontología, Universidad Complutense, Madrid.

Fernández-López, S. 1987: Necrocinesis y colonización posmortal en Bajocisphinctes (Ammonoidea) de la Cuenca Ibérica. Implicaciones paleoecológicas y paleobatimétricas. Boletin de la Real Sociedad Española de Historia Natural, (Sección Geológica) 82, 151-184.

Fernández-López, S. 1991. Taphonomic concepts for a theoretical Biochronology. Revista Española de Paleontología 6, 37-49.

Fernández-López, S. 1995. Taphonomie et interprétation des paléoenvironnements. In Gayet, M. \& Courtinat, B. (eds): First European Palaeontological Congress, Lyon 1993. Geobios M.S. 18, 137-154.
Fernández-López, S. 2000a. Ammonite taphocycles in carbonate epicontinental platforms. In Hall, R.L. \& Smith, P.L. (eds): Advances in Jurassic Research 2000. Geokesearch Forum 6, 293-300.

Fernández-López, S. 2000 b: Lower Bathonian ammonites of Serra de la Creu (Tivissa, Catalan Basin, Spain). Revue de Paléobiologie 8, 4552.

Fernández-López, S.R. \& Henriques, M.H. 2002: Upper BajocianLower Bathonian ammonites of Cabo Mondego section (Portugal). In Martire, L. (ed.): 6th International Symposium on the Jurassic System, Abstracts and Programs 65-66. International Subcommision on Jurassic Stratigraphy, Mondello.

Galácz, A. 1980: Bajocian and Bathonian Ammonites of Gyenespuszta Bakony Mts., Hungary. Geologica Hungarica 39, 1-228.

Galácz, A. 1994: Ammonite stratigraphy of the Bathonian red limestone of the Mecsek Mts, south Hungary. Annales Universitatis Scientiarum udapestinensis 30,111-150.

Galácz, A. 1999: A Lower Bathonian ammonite fauna from Erice (Western Sicily). Annales Universitatis Scientiarum Budapestinensis $32,149-168$

Gauthier, H. 2003: Mise au point et compléments sur la biostratigraphie et la taxonomie de la sous-famille des Garantianinae (Stephanoceratidae, Ammonoidea). Revue de Paléobiologie 22, 261-267.

Géczy, B. \& Galácz, A. 1998: Bathonian ammonites from the classic Middle Jurassic locality of Villány, South Hungary. Revue de Paléobiologie 17, 479-511.

Henriques, M. \& Ramalho, M.M. 2005: Jurassic Heritage of Cabo Mondego (Central Portugal). In Henriques, M.H. (Coord.): Jurassic Heritage and Geoconservation in Portugal: Selected Sites. Field Trip Guide Book. IV International Symposium ProGE on the Conservation of the Geological Heritage, 37-43. Geosciences Centre, Coimbra.

Halm, W. 1969: Die Perisphinctidae STEINMANN (Ammonoidea) des Bathoniums (Brauner Jura $\varepsilon$ ) im südwestdeutschen Jura. Jahreshefte des geologischen Landesamt Baden-Württemberg 11, 29-86.

Halm, W. 1970: Die Parkinsoniidae S. BUCKMAN und Morphoceratidae HYATT (Ammonoidea) des Bathoniums (Brauner Jura $\varepsilon$ ) im südwestdeutschen Jura. Jahreshefte des geologischen Landesamt Baden-Württemberg 12, 7-62.

Innocenti, M., Mangold, Ch., Pavia, G. \& Torrens, H.S. 1988: A proposal for the formal ratification of the basal boundary stratotype of the Bathonian Stage based on a Bas Auran section (S.E. France). In Rocha, R.B. \& Soares, A.F. (eds): 2nd International Symposium on Jurassic Stratigraphy, 333-346. Centro de Estratigrafia e Paleobiologia, Universidade Nova de Lisboa, Lisboa.

Krystyn, L. 1972: Die berbajocium- und Bathonium-Ammoniten der Klaus-Schichten des Steinbruches Neumühle bei Wien (Österreich). Annalen des Naturhistorischen Museum in Wien 76, 195-310.

Mangold, Ch. 1971a: Stratigraphie des étages Bathonien et Callovien du Jura Méridional. Documents des Laboratoires de Géologie de la Faculté des Sciences de Lyon 41, 1-376.

Mangold, Ch. $1971 \mathrm{~b}$ : Les Perisphinctidae (Ammonitina) du Jura Méridional au Bathonien et au Callovien. Documents des Laboratoires de Géologie de la Faculté des Sciences de Lyon 41, 1-246.

Mangold, Ch. 1971c: Morphoceratidae (Ammonoidea, Perisphinctidae) bathoniens du Jura méridional, de la Nièvre et du Portugal. Geobios 3 (1970), 43-130.

Mangold, Ch. 1981: Le Bathonien de l'Est du Subbétique (Espagne du Sud). Cuadernos de Geología 10 (1979), 271-281.

Mangold, Ch. 1990: Le Bathonien du Cap Mondego ( $N$ de Figueira da Foz, Portugal). Biochronologie et corrélations. Cahiers de lUniversité Catholique de Lyon 4, 89-105.

Mangold, Ch. 1997: Tendances évolutives chez les Morphocératidés (Périsphinctacés, Ammonitina). Cahiers de l'Université Catholique de Lyon 10, 9-101.

Mangold, Ch. \& Rioult, M. 1997: Bathonien. In Cariou, E. \& Hantzpergue, P. (eds): Biostratigraphie du Jurassique ouest-européen et méditerranéen. Bulletin du Centre de Recherches Elf Exploration Production, Mémoires 17, 55-62.

Martire, L. \& Pavia, G. 2004: Jurassic sedimentary and tectonic processes at Montagna Grande (Trapanese Domain, Western Sicily, Italy). Rivista Italiana di Paleontologia e Stratigra fia 110, 23-33. 
Matyja, B.A. \& Wierzbowski, A. 2000: Ammonites and stratigraphy of the uppermost Bajocian and Lower Bathonian between Czestochowa and Wielun, Central Poland. Acta Geologica Polonica 50, 191-209.

Mihajlovic, M. 1969: The ammonite fauna of the Dogser sediments of the Klauss facies of the environs of Donji Milanovac (East Serbia). Bulletin of the Natural History Museum 2, 45-125.

Mitta, V.V. \& Seltzer, V.B. 2002: First finds of Arctocephalitinae (Ammonoidea) in the Jurassic of the south-eastern Russian Platform, and the correlation of the Boreal Bathonian Stage with the standard scale. Transactions of the Scientific Research Geological Institute of the N.G. Chernyshevskii Saratov State University 10, 12 39.

Moyne, S., Neize, P., Marchand, D. \& Thierry, J. 2004: Répartition mondiale des faunes d'ammonites au Jurassique moyen (Aalénien supérieur à Bathonien moyen): relations entre biodiversité et paléogéographie. Bulletin de la Société géologique de France 175, $513-523$.

- livero, D., Manzold, Ch. \& Pavia, G. 1997: La formation des Calcaires à Zoophycos du Verdon (Bathonien inférieur à Callovien moyen) des environs de Castellane (Alpes-de-Haute-Provence, France): biochronologie et lacunes. Comptes Rendus de l'Académie des Sciences de Paris 324, 33-40.

Page, K.N., 1996a: Mesozoic Ammonoids in space and time. In Landmann, N.H., Tanabe, K. \& Davis, R.A. (eds): Ammonoid Paleobiology. Topics in Geobiology 13, 755-794.

Page, K.N. 1996b: bservations on the succession of stratigraphically useful ammonite faunas in the Bathonian (Middle Jurassic) of south-west England, and their correlation with a Sub-Mediterranean "Standard Zonation". Proceedings of the Ussher Society 9, 45-53.

Pavia, G. 1973: Ammoniti del Baiociano superiore di Digne (Francia SE, Dip. Basses-Alpes). Bollettino della Società Paleontologica Italiana, 10, 2 (1971), 75-142.

Pavia, G., Martire, L., Canzoneri, V. \& D'Arpa, C. 2002: Rocca chi Parra quarry, a condensed Rosso Ammonitico succession: depositional and erosional geometries, neptunian dykes and ammonite assemblazes. Catalano, R., Lo Cicero, G. \& A. Sullo: Geolozy of Sicily: an introduction. In Santantonio, M. (ed.): General Field Trip Guidebook, VI International Symposium on the Jurassic System, 4248. Palermo.

Rioult, M., Contini, D., Elmi, S. \& Gabilly, J. 1997: Bajocien. Bulletin du Centre de Recherches Elf Exploration Production, Mémoires 17 $41-53$.

Rocha, R., Manuppella, G., Mouterde, R., Ruget, Ch. \& Zbyszewski, G. 1981: Carta geológica de Portugal, 1/50000, folha 19-C, Figueira da Foz. Serviços Geológicos de Portugal, Lisboa.

Rocha, R.B., Mouterde, R., Soares, A.F. \& Elmi, S. 1987: Excursion A Biostratigraphie et évolution séquentielle du Bassin au Nord du Tage au cours du Lias et du Dogger. 84 pp. International Subcommission on Jurassic Stratigraphy, Centro de Estratigrafia e Paleobiologia da UNL (INIC), Lisboa.

Ruget-Perrot, Ch. 1961: Études stratigraphiques sur le Dogser et le Malm inférieur du Portugal au Nord du Tage. Servicos Geológicos de Portugal, Mémoire 7, 1-197.

Sandoval, J. 1983: Bioestratigrafia y paleontologia (Stephanocerataceae Perisphinctaceae) del Bajocense $y$ Bathonense en las Cordilleras Béticas. 613 pp. Tesis Doctoral, Universidad de Granada, Granada.

Sandoval, J. 1990: A revision of the Bajocian divisions in the Subbetic Domain (southern Spain). Memoire descrittive della Carta Geologica d'Ttalia $40,141-162$
Sandoval, J., 'Dogherty, L. \& Guex, J. 2001: Evolutionary rates of Jurassic ammonites in relation to sea-level fluctuations. Palaios 16 , $311-335$.

Schlög1, J. \& Rakús, M. 2004: Ammonites of Arabian origin from the Early Bathonian of the Czorsztyn Unit, Pieniny Klippen Belt (Western Carpatians, Slovakia). Neues Jahrbuch für Geologie und Paläontologie, Monatshefte 2004, 449-460.

Schlögl, J., Rakús, M., Mangold, C. \& Elmi, S. 2005: BajocianBathonian ammonite fauna of the Czorsztyn Unit, Pieniny Klippen Belt (Western Carpathians, Slovakia); its biostratigraphical and palaeobiogeographical significance. Acta Geologica Polonica 55, 339-359

Seyed-Emami, K., Schairer, G. \& Alavi-Naini, M. 1989: Ammoniten aus der unteren Dalichai-Formation (Unterbathon) östlich von Semnan (SE-Alborz, Iran). Müncher geowissenschaftliche Abhandlungen 15, 79-91.

Soares, A.F., Rocha, R.B., Elmi, S., Henriques, M.H.P., Mouterde, R., Alméras, Y., Ruget, Ch., Marques, J.F., Duarte, L.V., Carapito, M.C. \& Kullberg, J.C. 1993: Le sous-bassin nord lusitanien: histoire d'un rift avorté (Trias-Jurassique moyen, Portugal). Comptes Rendus de l'Académie des Sciences de Paris 317, 1659-1666.

Stephanov, J. 1966: The Middle Jurassic ammonite genus Cecotraustes Waagen. Travaux sur la Geologie de Bulgarie 8, 29-69.

Stephanov, J. 1972: Monograph on the Bathonian ammonite genus Siemiradzkia Hyatt, 1900 (nomenclature, taxonomy and phylogeny). Travaux sur la Geologie de ulgarie 21, 5-82

Sturani, C. 1967: Ammonites and stratigraphy of the Bathonian in the Digne-Barrême area (South Eastern France). Bolletino della Società Paleontologica Italiana 5, 3-57.

Torrens, H. 1987: Ammonites and stratigraphy of the Bathonian rocks in the Digne-Barrême area (South-Eastern France, Dept. Alpes de Haute Provence). Bolletino della Società Paleontologica Italiana 26, 93-108.

Tserethely, I.D. 1968: Les ammonites bathoniennes de la Georgie. 100 pp. Tbilisi.

Watkinson, M. P. 1989: Triassic to Middle Jurassic sequences from the Lusitanian Basin Portugal, and their equivalents in other North Atlantic margin basins. $390 \mathrm{pp}$. Unpublished Ph Thesis, The pen University, Milton Keynes, UK.

Wendt, J. 1963: Stratigraphisch-paläontologische Untersuchungen im Dogger Westsiziliens. Bolletino della Societa Paleontologica Italiana 2 , $57-145$.

Wendt, J. 1971: Geologia del Monte Erice (provincial di Trapani, Sicilia occidentale). Geologica Romana 10, 53-76.

Westermann, G. 1956: Phylogenie der Stephanocerataceae und Perisphinctaceae des Dogzer. Neues Jahrbuch für Geologie und Paläontologie, Abhandlungen 103, 233-279.

Westermann, G. 1958: Ammoniten-Fauna und Stratigraphie des Bathonien NW-Deutschlands. Beihefte zum Geologischen Jahrbuch $32,1-103$.

Westermann, G.E.G. \& Callomon, J.H. 1988: The Macrocephalitinae and associated Bathonian and Early Callovian (Jurassic) ammonoids of the Sula Islands and New Guinea. Palaeontographica 203, 1-90.

Wetzel, W. 1937: Studien zur Paläontologie des nord-westeuropäischen Bathonien. Palaeontographica 87, 77-157.

Zaton, M. \& Marynowski, L. 2004: Konzentrat-Lagerstätte-type carbonate concretions from the uppermost Bajocian (Middle Jurassic) of the Czêstochowa area, South-Cental Poland. Geological Quarterly 48, 339-350. 